\title{
Determinants Factors of Non-Performing Financing in Islamic Microfinance Institution (Case study of Islamic Cooperative XYZ in Sidoarjo, Indonesia)
}

\section{Hayu Maulida and Bayu Arie Fianto}

Department of Islamic Economics, Faculty of Economics and Business, Universitas Airlangga

\section{Abstract}

This paper investigates the influence ofsocio-economics, geographic location, and financing characteristics of clients from Islamic microfinance institution towards their financing performance. Using chi-square models,the data were collected from 140 clients of one Islamic microfinance institution in Sidoarjo city in Indonesia. The results show that sex, occupation, location, type of contract, and total financing influence the non-performing financing of Islamic microfinance institution in Indonesia.

Corresponding Author: Hayu Maulida hayumaulida@gmail.com

Received: 10 February 2019 Accepted: 14 March 2019 Published: 28 March 2019 Publishing services provided by Knowledge E

(c) Hayu Maulida and Bayu Arie Fianto. This article is distributed under the terms of the Creative Commons Attribution License, which permits unrestricted use and redistribution provided that the original author and source are credited.

Selection and Peer-review under the responsibility of the ICIEBP Conference Committee.
Keywords: Socio-Economic, Geographical Location, Characteristics of Financing, Non-Performing Financing, Chi-square

\section{Introduction}

Microfinance institutions (MFIs) are financial institutions that aimed to help and provide financing for middle and small classes of the society. Besides providing financial services to the community, it also helps to develop clients' business and empower them (Otoritas Jasa Keuangan, 2016).

Islamic MFI is institution that has Islamic value and follow Islamic law that can be a solution for people who are not able to access formal financial institution (e.g. bank). In addition,this institution can also become a solution for Muslim in rural areas which reluctant to borrow from conventional institution that involved interest or riba in its transaction (Ahmad and Ahmad, 2009).

Various types of Islamic microfinance institutions in Indonesia according to Soemitra (2009) are zakah management institutions, waqf management institutions, baitul mal wat tamwil (BMT) and sharia cooperatives. Operationally, from the four institutions, 
there are two of them who have similar operational activities, namely BMT and sharia cooperatives (Soemitra, 2009).

The development of sharia cooperatives in Indonesia is promising (Umam, 2016). As a profit-oriented business institution, Islamic cooperatives are also considered capable of performing social functions in which social funds can be collected by this institution and channeled to the rightful parties (Burhanuddin, 2013). Social funds that can be collected by Islamic cooperatives including, zakah(The form of worship to Allah SWT by issuing part of his property, the law is obligatory and given to certain groups with a certain amount), infaq (Sedekah in the form of objects, the sunnah law, there is no certain nominal limit), sedekah (The good that we give to others in any form, the sunnah law), and waqf (Submit long-lasting property rights to nadzir both individuals and management bodies provided the results or benefits are used in accordance with Islamic sharia) (Burhanuddin, 2013).

Financing is the distribution of funds provided by financial institutions to those who need funds where these funds come from people who have excess funds (Afandi, 2009; Nuryadin, 2004).

The provision of financing based on sharia principles is based on analysis by applying the precautionary principle so that the debtor is able to repay his debt or return the financing in accordance with the agreement so that the risk of failure in payment can be avoided (Djamil, 2012).

In general, the thing faced by all sharia financial institutions that provide financing facilities is the same.It is related to the return of financing which is very vulnerable causing problematic financing, including in Islamic cooperatives (Afandi, 2009).

The ability to return the financing of clients to financial institutions is not always good.In fact, the debtor is often unable to return the performing financing, so it results in non-performing financing (Fuady, 1995).

The long-term impact of non-current returns will make the financing function of Islamic financial institutions, especially Islamic cooperatives, disrupted such as the lack of maximum funding for the public who need funds for productive and consumptive activities (Djamil, 2012). Therefore, Islamic cooperatives become difficult to develop, operate perfunctory and result in lowering the trust of clients (Burhanuddin, 2013). Conversely, if the return on performing financing, then the financing function of Islamic financial institutions becomes maximal and the quality of the portfolio of the financial institution is also good (Nuryadin, 2004).

This study attempts to examine the factors that influence non-performing financing using socio-economic aspects of financing clients (age, sex, education level, type of 
work), geographical aspects (distance and location), and financing characteristics (types of contracts and total financing).

Several studies have tried to explain the factors that influence the level of nonperforming financing. However, there are only a few empirical studies that explain it. Thus, the author intends to know and analyze any influence on non-performing financing in the $\mathrm{XYZ}$ Islamic cooperative.

\section{Characteristics}

\subsection{Socioeconomics}

According to Supartono (2011), socio-economic factors can consist of: (1) level of income, (2) level of consumption, (3) level of production, (4) level of education, (5) work ethic, (6) type of work, (7) population, (8) and so on. Accordingly, socio-economic factors are factors that describe social conditions and economic conditions of someone who interacts with each other (Damsar, 2009).

There are several socio-economic factors in the community, including (1) sex, (2) income level, (3) education level, (4) residence, (5) type of work, (6) age, and (7) economic activity (Waluya, 2007). This study uses four socio-economic variables, including age, sex, level of education, and type of work because in general, the Islamic cooperative institutions with these four variables are the form of debtor identifiers before being approved for financing.

\subsection{Geographics}

Spatial analysis for a geographer is the main thing that must be understood because it examines various aspects, both physically, socially, location, and human activities. This variable is different from one place to another. Factors that influence the pattern of spatial distribution or distribution of elements are usually related to many factors. An example is a relationship between social aspects. Such as the distance of the house from the road to the density of the house or the value of land. This study uses two geographic aspect variables, including distance and location because it will be the form of the debtor's identifier before being approved for financing. 


\subsection{Financing characteristics}

Financing for microfinance institutions is divided into four categories, namely financing based on profit sharing contracts, buying and selling contracts, and supplementary contracts. Financing based on profit sharing contracts includes mudharabah and musyarakah financing, while financing based on buying and selling contracts includes murabahah financing, salamfinancing, and istishna financing. Financing under the lease principle includes ijarah and IMBT financing. While financing with complementary contracts is intended to facilitate financing using the three principles above (Nafi'ah, 2008).

\section{Literature Review}

There are several results from previous studies that were used as references from this study. The research conducted by Lubis and Rachmina (2011) entitled Factors Affecting Realization and Returns of People's Business Credit shows that sex, monthly obligations, repayment period and education level have a significant effect on the rate of return on people's business loans. The results of hypothesis testing indicate that sex, monthly obligations, repayment period and level of education have a significant effect on the rate of return on people's business credit.

Next research by Kiswati and Rahmaway (2015) was entitled Factors Affecting the Return Rate of Mudharabah Financing. This research was conducted at the Fastabiq BMT in Batangan, Pati. The independent variables used were education level, number of family dependents, business turnover, and length of business. The results of the hypothesis indicated that all independent variables had a significant positive effect on the rate of return on financing.

Research conducted by Prestisia (2017), this study resulted in a hypothesis test that age, loan amount, loan repayment period and collateral value had a significant effect on performing financing, while the education level did not significantly influence the performing financing.

A study by Kusumaningrum (2018) was entitled Factors Affecting the Return of Revolving Loans of Self-Help Groups at the Ngagel Rejo Mulyo BKM (Case Study at the Ngagel Rejo BKM). This study used independent sex variables, group loan amounts, and total group member income, and the dependent variable returns on revolving loans. The results of the hypothesis indicated that sex and the number of group loans had a significant positive effect on the return of revolving loans, while the total income of group members had no significant effect on the return of revolving loans. 


\section{Methodology}

This research uses financing client data on Islamic cooperative $X Y Z$ in Sidoarjo because Islamic cooperative $\mathrm{XYZ}$ is one of the large cooperatives in Sidoarjo. Data from 140 clients was obtained through purposive sampling in Islamic cooperative XYZ in Sidoarjo. This study used secondary data, namely financial statement data in the form of data on clients who conducted performing financing and non-performing financing. The data was based on the collectibility level of financing as a sample.

The variables in this study were three groups, namely socio-economic(age, sex, education level, and type of occupation), geography (distance and location), financing characteristics (type of contract and total financing). Table 1 presents the definitions of variables used in the empirical model.

TABLE 1: Description of variables.

\begin{tabular}{|c|c|c|}
\hline Wabiles & Type ar wable & Descrption of wantlet \\
\hline \multicolumn{3}{|l|}{ Sorictrassuks: } \\
\hline Are & Cuthmon & Are of alane (a yeni) \\
\hline Sns & Dhemy & Sex of eligata $(1-k$ kede, omale $)$ \\
\hline Eductions hetel & Dunmy & 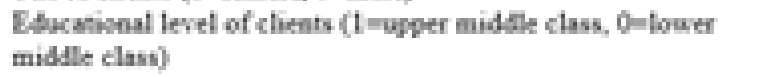 \\
\hline 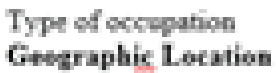 & Duamy & 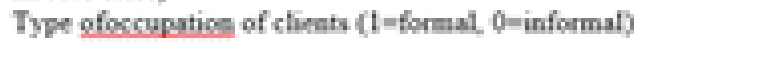 \\
\hline Ditanct & Dhumy & 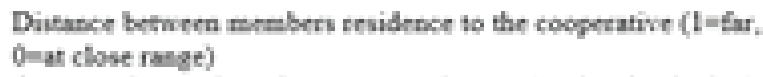 \\
\hline 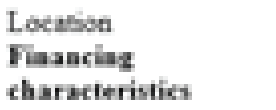 & Dhermy & 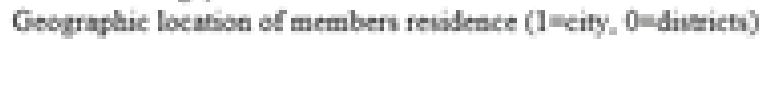 \\
\hline Typed econtrat & Dusmy & Contract umd in fancing (1-PLS, 0-Won-PLS) \\
\hline Toral fowsing & Duसmy & Chents mal trancing \\
\hline
\end{tabular}

The method of selecting samples used in this study was the purposive sampling method. Purposive sampling is a technique of determining samples with certain considerations (Sugiyono, 2014).

\section{Empirical Result and Discussion}

\subsection{Socio-economics}

Table 2 summarized the general characteristics of clients. The result indicated thatclients who conductnon-performing financingweremostly found in age 36-55 (84.0\%). The reason was because those who performed financing generally came from those age range.In terms of sex, non-performing financing wasconducted more by male (60.0\%). It may happen as men did not carefully make a decision. Regarding to education level, clients who completed senior high school or known as upper middle class tended 
to conductnon-performing financing (90.0\%). It occurred because most clients who performed financing belong to upper middle class, so that they contributed more in nonperforming financing. Moreover, most of clientswhoconducted non-performing financing had informal work (86.0\%) because of non-fixed income earned by them every month (see Table 2).

TABLE 2: Profile of the clients.

\begin{tabular}{|c|c|c|c|c|c|c|c|c|}
\hline \multirow[t]{2}{*}{ Variable } & & \multicolumn{2}{|c|}{$\begin{array}{c}\text { Non-performing } \\
\text { financing } \\
(\mathrm{N}=50)\end{array}$} & \multicolumn{2}{|c|}{$\begin{array}{l}\text { Performing financing } \\
\qquad(\mathrm{N}=90)\end{array}$} & \multicolumn{2}{|c|}{$\begin{array}{c}\text { Total } \\
(\mathrm{N}=140)\end{array}$} & \multirow[t]{2}{*}{ Chi-square } \\
\hline & & Sub-total & $\%$ to $\mathrm{N}$ & Sub-total & $\%$ to $\mathrm{N}$ & Sub-total & $\%$ to $\mathrm{N}$ & \\
\hline \multirow[t]{5}{*}{ Age } & $21-35$ th & 1 & $2.0 \%$ & 8 & $8.9 \%$ & 9 & $6.4 \%$ & \\
\hline & $36-55$ th & 42 & $84.0 \%$ & 75 & $83.3 \%$ & 117 & $83.6 \%$ & \\
\hline & $56-70$ th & 7 & $14.0 \%$ & 7 & $7.8 \%$ & 14 & $10.0 \%$ & 37.3203 \\
\hline & Total & & $100.0 \%$ & & $100.0 \%$ & & $100.0 \%$ & \\
\hline & Mean & 46.38 & & 46.47 & & 46.44 & & \\
\hline \multirow[t]{3}{*}{ Sex } & Female & 20 & $40.0 \%$ & 73 & $81.1 \%$ & 93 & $66.4 \%$ & \\
\hline & Male & 30 & $60.0 \%$ & 17 & $18.9 \%$ & 47 & $33.6 \%$ & $24.3600^{* * *}$ \\
\hline & Total & & $100.0 \%$ & & $100.0 \%$ & & $100.0 \%$ & \\
\hline \multirow[t]{4}{*}{ Education level } & $\begin{array}{l}\text { Upper Middle } \\
\text { Class }\end{array}$ & 45 & $90.0 \%$ & 80 & $88.9 \%$ & 125 & $89.3 \%$ & \\
\hline & Lower Middle & 5 & $10.0 \%$ & 10 & $11.1 \%$ & 15 & $10.7 \%$ & 0.0415 \\
\hline & Class & & & & & & & \\
\hline & Total & & $100.0 \%$ & & $100.0 \%$ & & $100.0 \%$ & \\
\hline \multirow[t]{3}{*}{ Type of work } & Formal & 7 & $14.0 \%$ & 5 & $5.6 \%$ & 12 & $8.6 \%$ & \\
\hline & Informal & 43 & $86.0 \%$ & 85 & $94.4 \%$ & 128 & $91.4 \%$ & $2.9248^{*}$ \\
\hline & Total & & $100.0 \%$ & & $100.0 \%$ & & $100.0 \%$ & \\
\hline \multirow[t]{3}{*}{ Distance } & $\operatorname{Far}(11-25 \mathrm{~km})$ & 11 & $22.0 \%$ & 20 & $22.2 \%$ & 31 & $22.1 \%$ & \\
\hline & $\begin{array}{l}\text { At close range } \\
(1-10 \mathrm{~km})\end{array}$ & 39 & $78.0 \%$ & 70 & $77.8 \%$ & 109 & $77.9 \%$ & 0.0009 \\
\hline & Total & & $100.0 \%$ & & $100.0 \%$ & & $100.0 \%$ & \\
\hline \multirow[t]{3}{*}{ Location } & City & 22 & $44.0 \%$ & 54 & $60.0 \%$ & 76 & $54.3 \%$ & \\
\hline & District & 28 & $56.0 \%$ & 36 & $40.0 \%$ & 64 & $45.7 \%$ & $3.3158 *$ \\
\hline & Total & & $100.0 \%$ & & $100.0 \%$ & & $100.0 \%$ & \\
\hline \multirow{3}{*}{ Type of contract } & PLS & 42 & $84.0 \%$ & 30 & $33.3 \%$ & 72 & $51.4 \%$ & \\
\hline & Non-PLS & 8 & $16.0 \%$ & 60 & $66.7 \%$ & 68 & $48.6 \%$ & $33.0327^{* * *}$ \\
\hline & Total & & $100.0 \%$ & & $100.0 \%$ & & $100.0 \%$ & \\
\hline \multirow[t]{10}{*}{ Total Financing } & $<3,000,000$ & 5 & $10.0 \%$ & 24 & $26.7 \%$ & 29 & $20.7 \%$ & \\
\hline & IDR & & & & & & & \\
\hline & $\begin{array}{l}3,000,001- \\
8,000,000 \text { IDR }\end{array}$ & 16 & $32.0 \%$ & 37 & $41.1 \%$ & 53 & $37.8 \%$ & \\
\hline & $\begin{array}{l}8,000,001- \\
18,000,000\end{array}$ & 11 & $22.0 \%$ & 15 & $16.7 \%$ & 26 & $18.6 \%$ & \\
\hline & IDR & & & & & & & \\
\hline & $\begin{array}{l}18,000,001- \\
30,000,000 \\
\text { IDR }\end{array}$ & 10 & $20.0 \%$ & 10 & $11.1 \%$ & 20 & $14.3 \%$ & $12.9921^{* 8}$ \\
\hline & $>30,000,000$ & 8 & $16.0 \%$ & 4 & $4.4 \%$ & 12 & $8.6 \%$ & \\
\hline & IDR & & & & & & & \\
\hline & Total & & $100.0 \%$ & & $100.0 \%$ & & $100.0 \%$ & \\
\hline & Mean & $22778^{*}$ & & $9357^{*}$ & & $14150^{*}$ & & \\
\hline
\end{tabular}

*in thousands

$* 10 \%$ significant level

$* * 5 \%$ significant level

$* * * 1 \%$ significant level

\subsection{Geographic location}

Clients who livedclosely to the cooperative tended to conduct non-performing financing more (78.0\%) than those who lived far from the cooperative (22\%). The possible reason 
was because they oversimplified the financing as they lived closely to the cooperative. Furthermore, clients who conducted non-performing financing were those whose residence was in the district (56.0\%). This finding may due to the fact that the ease of access to the coorperative influenced clients' behavior. Accordingly, people who lived in the district conduct non-performing financing (see Table 2).

\subsection{Financing characteristics}

Regarding to the type of contract, clients who conducted non-performing financing were in PLS contract (84.0\%). It was likely to happen because there was a moral hazard in PLS contract. In terms of the total financing made by the clients, clients who received financing between 3,000,001-8,000,000 IDR (32.0\%) conducted nonperforming financing category (see Table 2 ).

The result showed that clients' sex influenced the non-perfoming financing, and the result was consistent with the previous microfinance research in which the proportion of high female borrowers to loan repayments had a low risk due to the nature of women who had a higher sense of responsibility in returning loans compared to the male borrower (Kusumaningrum, 2018). In terms of the type of work, the result indicated that clients who had formal employment were better in performing financing. The result was in line with the research conducted by Prestisia (2017). In general, jobs that with fixed income were more likely to have a small risk of returning financing compared to jobs without steady income. The finding also shows that location from city, the higher possibility of borrowers to repay their loan. Being location from city, will give an extra advantage, a borrowers to repay their loan. On the type of contract, the result of the study indicated that the clients whose type of profit was loss sharing contract, had the possibility of conducting non-performing financing. While, the higher the total loan received by the borrowers, the higher probability of borrowers to pay their loan on time. This is because the borrowers have enough funds to finance their business that makes them get more profit and increase their business profile.

\section{Conclusions}

This study analyzes the factors that influence non-performing financing. The results show that there are eight factors that influence the non-performing financing namely age, sex, education level, type of work, a distance of residence to a cooperative, a location of residence, type of contract, and total financing. This study finds that there 
are 5 variables that have the most dominant influence on the non-performing financing compared to other variables namely sex, type of work, location, type of contract, and total financing. Therefore sex, especially in men, has an influence on the non-performing financing. This is based on the attitude and nature of men that tend to take risks. This study shows that the type of informal work has an influence on non-performing financing.This statement is based on non-fixed income every month earned by clients, so that they cannot estimate how to divide the income to meet daily needs.

The type of PLS contract has an influence on the non-performing financing. This is because the PLS contract has a proportion that fits the needs of the client.

\section{References}

[1] Afandi, M. Y. (2009). Fiqh Muamalah dan Implementasinya dalam Lembaga Keuangan Syariah. Yogyakarta: Logung Pustaka.

[2] Ahmad, A. U. F., Ahmad, A. B. R. (2009). Islamic microfinance: the evidence from Australia. Humanomics, 25(3), 217-235. https://doi.org/https://doi.org/10.1108/08288660910986946

[3] Burhanuddin. (2013). Koperasi Syariah dan Pengaturannya di Indonesia. Malang: UIN Maliki Press.

[4] Djamil, F. (2012). Penyelesaian Pembiayaan Bermasalah di Bank Syariah. Jakarta: Sinar Grafika.

[5] Fianto, B. A., Gan, C., Hu, B., Roudaki, J. (2017). Equity Financing and Debt-based Financing: Evidence from Islamic Microfinance Institutions in Indonesia. Pasific-Basin Finance Journal. https://doi.org/http://dx.doi.org/10.1016/j.pacfin.2017.09.010

[6] Fuady, M. (1995). Hukum Tentang Pembiayaan Dalam Teori dan Praktek (Leasing, Factoring, Modal Ventura, Pembiayaan Konsumen, Kartu Kredit). Bandung: Citra Aditya Bhakti.

[7] Kiswati, Rahmaway, A. (2015). Faktor-Faktor yang Mempengaruhi Tingkat Pengembalian Pembiayaan Mudharabah. Ekonomi Syariah, Equilibrium, 3(1).

[8] Kusumaningrum, A. (2018). Faktor-Faktor yang Mempengaruhi Pengembalian Pinjaman Bergulir Kelompok Swadaya Masyarakat di BKM Ngagel Rejo Mulyo. Thesis. Airlangga.

[9] Littlefield, E., Morduch, J., Hashemi, S. (2003). Is microfinance an effective strategy to reach the millennium development goals? Focus Note 24 (2003), 1-11.

[10] Lubis, A. M., dan Rachmina, D. (2011). Faktor-Faktor yang Mempengaruhi Realisasi dan Pengembalian Kredit Usaha Rakyat. Forum Agribisnis, 1(2), 112-131. 
[11] Nafi'ah, S. J. (2008). Profit Loss Sharing dan Moral Hazard dalam Penyaluran Dana Pihak Ketiga. Islam Negeri Sunan Kalijaga.

[12] Nuryadin, H. (2004). BMT dan Bank Islam: Instrumen Lembaga Keuangan Syari'ah. Bandung: Pustaka Bani Quraisy.

[13] Otoritas Jasa Keuangan. (2016). Statistik Lembaga Keuangan Mikro Indonesia.

[14] Prestisia, E. (2017). Pengaruh Usia, Tingkat Pendidikan, Jumlah Pinjaman, Jangka Waktu Pengembalian Pinjaman dan Nilai Jaminan Terhadap Kelancaran Pengembalian Pembiayaan Pada BMT Amal Rizki di Gunung Kidul. UIN Sunan Kalijaga. Retrieved from https://digilib.uin-suka.ac.id:80/id/eprint/26387

[15] Soemitra, A. (2009). Bank \& Lembaga Keuangan Syariah. Jakarta: Pranedamedia Group.

[16] Sugiyono. (2014). Metode Penelitian Kuantitatif, Kualitatif, dan R\&D. Bandung: ALFABETA CV.

[17] Supartono. (2011). Analisis Variabel Sosial Ekonomi Masyarakat Urban terhadap Kemandirian Ekonomi Ditinjau dari Aspek Keuangan, Energi dan Pangan di Kecamatan Singosari Kabupaten Pemalang. Journal of Indonesian Applied Economics, 5(1).

[18] Umam, K. (2016). Perbankan Syariah: Dasar-Dasar dan Dinamika Perkembangannya. Jakarta: Rajawali Press.

[19] Waluya, B. (2007). Sosiologi. Bandung: PT Setra Puma Inves. 